\title{
WHAT'S IN A NAME? \\ RACIAL AND ETHNIC CLASSIFICATIONS AND THE MEANING OF HISPANIC/LATINO IN THE UNITED STATES
}

\author{
Keith M. Kilty \\ Ohio State University \\ Maria Videl de Haymes \\ Loyola University Chicago
}

\begin{abstract}
The first national census was conducted in 1790, and has been repeated at ten year intervals ever since. While census taking has been consistent, the way individuals have been counted and categorized on the basis of race and ethnicity has varied over time. This paper examines how the official census definition of Latinos has changed over the twenty-two census periods. The modifications of the official definition of this group are discussed in relation to changes in national borders, variations in methodology used for census data gathering, and shifting political contexts.
\end{abstract}

One of the most common scientific activities is classifying different objects into categories. In fact, classification is not only a scientific activity but a common human activity in general. "Sorting things out," as Bowker and Star (1999) put it, can be quite informal and part of our everyday lives as well as more formalized and organized as part of the scientific enterprise. In fact, classification is fundamental to science (Babbie, 2001). Observation and measurement require at a minimum the identification of categories to describe concepts, with the categories of a particular concept defined in such a way as to allow for nonambiguous sorting of objects into categories. That is the nature of the most basic level of measurement, the nominal, where all 


\section{Kilty and Haymes-Classifying}

objects must be classified into one (and only one) category, and all objects must be accounted for by a category.

Since at least the advent of modern science, people calling themselves scientists have engaged in the act of sorting things out. That includes the modern social scientific concepts of race and ethnicity. In fact, during the nineteenth century, when European expansion and imperialism dominated most of the world, racial classification became a critical issue, leading to what is now referred to as "scientific racism." Beginning with Thomas Malthus' Essay on the Principle of Population in 1798, European and American social scientists elaborated a wide variety of racial classification schemes, always leading to the conclusion that whites were the most advanced racial group. The French aristocrat Count Joseph Arthur de Gobineau was the first to distinguish white and black and yellow in 1853. The Social Darwinists, led by Herbert Spenser, used these ideas to justify European domination of the Americas, Africa, and Asia, while Francis Galton was the first to clearly argue that the superior inherited their superiority while the inferior inherited their inferiority. All of these ideas were cloaked in the legitimacy of "science," particularly through the tool of "classification." Yet, as Bowker and Star (1999) note, classification is not merely an objective process. It is shaped by the values and beliefs of those doing the classification.

All the same many social scientists have continued to argue that racial and ethnic classifications reflect nothing more than innocuous demographic processes. While race and ethnicity have political overtones, those dynamics are independent of the scientific process of classifying and counting. Is that an accurate portrayal of social science? Nobles (2000) argues that it is not, that, in fact, racial classification systems are inherently political processes. In the United States we can see how race infuses our ideas of who is part of the American community in examining the nature of citizenship. The first immigration legislation in this country was the Naturalization Act of 1790, which allowed only whites to become naturalized citizens (Kilty \& Vidal de Haymes, 2000; Takagi, 1989). African Americans were not given citizenship until the post-Civil War era through the Fourteenth 


\section{Ethnic Studies Review Volume 27: 1}

Amendment. Native Americans were not recognized as citizens until 1924 (Deloria \& Lytle, 1984); while it was not until the 1950 s that Asians born outside the U. S. could become naturalized citizens (Takagi, 1989). Racial classification, then, has been and continues to be a fundamental issue in our society, limiting how different groups have been allowed to participate in it.

Hispanics or Latinos are currently recognized as one of the most rapidly growing non-white groups in this country. But what exactly is a Hispanic or Latino? The Bureau of the Census identifies Hispanics as an "ethnic" group whose members can be of any "race." At one time, though, it also identified Mexicans as a racial group. There has been a Hispanic presence in the U. S. virtually since its beginning as a nation-state (Kilty \& Vidal de Haymes, 2000). While the purchase of Florida in 1819 may be considered the starting point, the numbers of Hispanics rose rapidly during the nineteenth century through $U$. S. colonial expansion, including the Mexican-American War of 1846-1848 and the Spanish-American War of 1898. A century later, the numbers escalated even more dramatically. Yet what does it mean to be Hispanic? Who becomes labeled and why?

\section{Classifying (and Defining) Race and Ethnicity}

For the most part race is no longer identified by social scientists as a biological variable. In fact, some argue that race is no longer as meaningful a force in American life as it once was (e.g., Wilson, 1978), and there is an ambivalence on the part of many people, particularly whites, to deal with race. Other social scientists have taken to using the term "ethnicity" in place of race. In a way this may be a broadening of the concept and a return to the nineteenth and early twentieth century when race itself was used in reference not only to skin color but also to such characteristics as nationality. Use of ethnicity as a substitute for race may also be a way for whites, whether social scientists or ordinary citizens, who are uncomfortable with race and racism to downplay the power of those forces in modern life. As Nobles (2000, 14) points out, "Scholars treat ethnic categorization as a benignly descriptive marker-albeit one sometimes used for politically objectionable ends-but race has always had political 
meanings and uses."

All the same, most members of this society still identify race (whether labeling it as "race" or as "ethnicity") as a social construct that has some continuing significance in people's lives (Farley, 2000). The question is the extent to which race is important. Most whites have accepted the idea that racism is largely a thing of the past. Yet, as Feagin, Vera, and Batur $(2001,13)$ note, "The substantial white consensus on the decline of racism is not based on empirical evidence." People in this society look upon and act toward each other based on their perceptions of other people in terms of racial and ethnic categories. Media images of certain groups as "criminal" or "welfare cheats" have affected social policy in terms of sentencing provisions for possession of particular illicit substances and changes in public assistance legislation (Kilty \& Joseph, 1999). Racism and discrimination cannot exist without the acceptance of racial classification. Clearly, there is a broadly-based consensus on specific racial categories in the U. S. and, for better or worse, an acceptance of these categories as having an "objective" reality, as being "natural."

What, then, is race? What does it mean to those of us living in this society? How does it affect our sense of group membership as well as self? To answer those questions we need to look at this concept somewhat differently, perhaps as a kind of "discourse." According to Nobles (2000, 13),

Today, although scientists reject race as a scientifically meaningful concept, whether race was (or is) viewed as "natural" is, in certain ways, quite beside the point. Scientific racial thought has never simply meant "proving" the biological reality of race. Equally important has been the role of scientific ideas in shaping political discourse and public policies.

In other words, scientific conceptions of social issues affect not only how scientists but also the rest of society understand and act on those issues. Scientific ideas are part of a social, political, and economic context (Meenaghan \& Kilty, 2004).

As noted earlier, race has played a prominent role in the history of the United States. Race was used to justify the enslavement of Africans and the destruction of Native Americans. The 


\section{Ethnic Studies Review Volume 27: 1}

Constitution of the United States adopted in 1787 justified removing citizenship from "non-free" persons but counting them as "three-fifths" of a free person for purposes of apportionment. It appeared in the Naturalization Act of 1790, where naturalized citizenship was made available only to white persons (Takagi, 1989). Not surprisingly, then, race has figured prominently in every U. S. census.

The fact that a "variable" is included in an "enumeration" is not the whole story. What is perhaps more important is how that "variable" is conceived by those doing the research. According to Nobles (2000, 15-16),

Census bureau statisticians treat racial enumeration as the task of devising appropriate categories and counting by them. Race and its use as a counter have been regarded as self-evident in a way that belies the conceptual and political wrangling surrounding the production of racial data. Most scholarly and popular books on censuses present racial categorization as a technical procedure in need of little explanation. An institutional history of the U. S. Census Bureau written by a former bureau director never mentions racial categorization's contentious history.

If those who are collecting the data see what they are doing as merely an objective task, then they are suggesting that they are impartial. Such impartiality provides a sense of legitimacy for their activities, making what they do more credible and acceptable to the rest of society, including political authorities. This is especially important now that census taking has come to be seen as an important activity in modern society, one endorsed and encouraged by such organizations as the United Nations (Nobles, 2000).

Simply because an activity is accepted as objective and impartial certainly does not mean that it is. That includes science. While most scientists now acknowledge that science is a human enterprise that takes place within a social, political, and economic context, most probably still believe that there is a greater degree of objectivity and impartiality than is actually the case and have substituted terms such as "scientific realism" to 
respond to their critics (Meenaghan \& Kilty, 2004).

In the same way census taking has maintained an aura of impartiality and objectivity. According to Nobles (2000, 17), "Social scientists, who have long recognized the role of other state institutions in shaping racial politics, have all but ignored census bureaus and censuses." Yet, census taking has played a crucial role in shaping conceptions of race in the $U$. S. and elsewhere. Racial categories have changed over time, reflecting the prevailing scientific beliefs of particular eras. Nobles (2000) shows how between 1850 and 1920 the conception of "mulatto" affected census racial categories as a reflection of a commitment to the concept of polygenism by American social scientists (i.e., the notion that humanity consists of several unequal species). Later changes in racial thinking, such as Social Darwinism in the early decades of the twentieth century (1990 to 1930) and then the so-called "one-drop rule" that dominated racial ideas between 1930 and 1960 and which supported segregation, were reflected in varying census categories. More recent years have reflected what Nobles (2000) characterizes as the post-civil rights era, as well as the 1977 Office of Management and Budget Statistical Directive No. 15, which created a uniform set of categories for race and ethnicity. The goal of Statistical Directive No. 15 was to help federal agencies ensure compliance with civil rights legislation, by requiring the use of standard racial and ethnic categories across all federal bureaus, including the Census Bureau. This directive created four "racial" categories (American Indian or Alaskan Native, Asian or Pacific Islander, Black, and White) and one "ethnic" category (Hispanic). The latter category of Hispanic may be of any race.

Since the first $U$. S. census of 1790 , racial (and ethnic) categories have been important facets of the information collected by the Census Bureau. Yet these categories themselves have helped to define what race is in America. For the first six censuses, the primary categories were White and Black. Then Mulatto, the mix of White and Black, started to show up, as well as Native Americans and particular kinds of Asians (e.g., Chinese). By the twentieth century, a wide array of racial cate- 


\section{Ethnic Studies Review Volume 27: 1}

gories were included in the census, but, as noted, within the context of racial theory of the time. As Nobles (2000) shows, the census classification systems helped to create the concept of race and what it means in this society.

Census authorities deny what Nobles is arguing: that they are engaged in creating definitions of race. They assert that they are merely applying objective categories for statistical and programmatic purposes. Their statements reflect institutional racism, which refers to institutional forms or practices that systematically benefit one racial group over another (Kilty \& Joseph, 1999). Institutional racism can be conscious and deliberate, but it can also be unconscious and indirect. Those in the dominant group often fail to see that their practices are discriminatory and may even deny that discrimination exists. Sentencing provisions, for example, for possession of cocaine vary substantially depending on the form of cocaine (crack vs. powder), which has led to racial bias in prison sentences between Blacks and Whites. Yet the U. S. Sentencing Commission has flatly denied racial bias, arguing instead that there is simply an appearance of bias (Kilty \& Joseph, 1999).

\section{The Meaning of Hispanic and Latino}

What it means to be white or black or red or yellow or brown in this society is at least partly constructed by the social scientists and bureaucrats and public officials who endorse and carry out the census. Part of the experience of a particular minority of color, then, is shaped by these "official" definitions of who we are and who we are not. In fact, part of that experience is reflected in whether one is even defined. The numbers of Hispanics or Latinos generally remained low in census counts until the 1960s. Is that, indeed, due to small numbers, or to the ways in which population groups have been identified, labeled, and counted?

Hispanics occupy a unique place in the racial and ethnic history of the United States. Unlike American Indians, they were not treated as a menace that needed to be removed. Unlike Africans, they were not formally enslaved. Unlike Asians, they were not legally excluded or denied citizenship. For the most 
part, they represent a group that was acquired through imperialism and empire-building, particularly the conquest of the American southwest. The Treaty of Guadalupe-Hidalgo, which concluded the Mexican-American War in 1848, ceded the northern half of Mexico to the United States. That treaty granted all residents of the area $U$. S. citizenship and continued rights of ownership of their lands. While the terms of the treaty were never enforced, questions about formal citizenship never were raised, nor was there concern about passage back and forth across the U. S.-Mexican border until the Great Depression era (Kilty \& Vidal de Haymes, 2000). Future land acquisitions by the U. S. involving territories inhabited by Latinos were also generally resolved by granting the peoples of those occupied territories formal independence (e.g., Cuba and the Philippines) or $U$. S. citizenship (e.g., Puerto Rico).

That certainly does not mean that Hispanics were thought of as the equals of Anglos. For the most part, they were treated as different-as outsiders and inferiors. One of the most poignant historical examples of their treatment in racial terms occurred in Arizona in the early 1900s. A group of forty Irish orphans were brought by Roman Catholic nuns from New York to a mining town in Arizona where they were to be placed with MexicanAmerican families. When they learned of the families with whom these children were to be placed, Anglos in the community were outraged that "white" children would be given to "Mexicans." The children were seized and the nuns and a priest nearly lynched. Ultimately, the situation would be resolved in the Arizona and United States Supreme Courts in racial terms as Gordon $(1999,296)$ notes, fundamentally in terms of "whiteness." As Gordon goes on to say,

No matter that particular Mexican mine workers made individual, free choices to "immigrate," their experience in the United States was structured by that of earlier Mexican residents who were involuntarily incorporated. Mexican American identity and discrimination against Mexican Americans were shaped by the U. S. conquest of Mexico and the consequent supremacy of Anglos. Correspondingly, the Anglo identity and expe- 
rience in the Southwest were shaped by the U. S. conquest of Mexico and the consequent subordination of Mexican Americans (Gordon, 1996, 180).

These early experiences by Mexican Americans would be repeated throughout the twentieth century, including the deportations of supposed "Mexicans" in California during the Great Depression (Schaeffer, 2000) and mass deportations of Mexican migrant laborers in the 1950s, when there was no longer the need for laborers that led to the creation of the bracero program (Garcia, 1980). Other groups of Hispanics have also been identified in racial and ethnic terms and faced discrimination and oppression (Gonzalez, 2000).

The experiences of any racial or ethnic group, then, are shaped by how they are defined. Racial categories not only vary from one society to another, but they can also vary from one era to another within the same society. Looking at the racial categories identified in U. S. censuses since 1790 clearly shows such change (Nobles, 2000). Currently, there is a racialization process occurring regarding Hispanics (Vidal de Haymes, Haymes \& Kilty, 2001), where racialization refers to the attachment of racial meaning to a group (Omi \& Winant, 1987). While such meaning may be imposed upon a group, it may also be sought by members of the group. In response to demands from various advocacy groups, the $U$. S. Office of Budget and Management allowed a public review of the 1977 Statistical Directive No. 15 beginning in 1993. This led to a revision in the race and ethnicity categories in the 2000 census (Nobles, 2000), with the addition of "other race" and "multiple-race" categories. Latinos were particularly responsive to these changes:

In accordance with a well-established pattern, $42 \%$ of Latinos identified themselves as 'other race,' and $97 \%$ of all respondents who declared themselves "other race" were Latino -a significant trend not emphasized in the press. In addition, $6 \%$ of Latinos took advantage of the new 'multiple race' option, compared with only $2 \%$ of the non-Hispanic population. In fact, of all the multirace combinations made possible by the new option, the most common was 'white' and 'some other 


\section{Kilty and Haymes-Classifying}

race,' which census officials said was checked mainly

by Hispanics (Morales, 2001).

To understand what it means to be Hispanic or Latino, one needs to understand how a group has been defined within the context of a particular society. One way that a group is defined is through some "official" process, such as how it is codified by a census bureau. That is the focus of this paper: how the U.S. Census Bureau has (or has not) defined "Hispanic" and/or "Latino" during the past two centuries. Categorizing members of a society and then counting (or not counting) them clearly affects their sense of group identity and citizenship.

There are other ways of looking at how groups are identified as well. In addition to "official" Census Bureau categories, social scientists have long conducted population surveys, which include racial and ethnic categorizations. While these may be consistent with those established by the Census Bureau and other government agencies, they may also vary substantially. This represents another source of information reflecting "official" (or expert) definitions of groups, including "standard" definitions used in periodic surveys, such as the General Social Survey or opinion polls (e.g., Gallup) and definitions used in surveys focused on particular groups, such as Hispanics.

One could also examine racial and ethnic categories described in social science textbooks. Since at least the late nineteenth century social science texts have existed, and these compilations may be used as reflections of the knowledge in particular fields that is accepted during a particular era (Meenaghan \& Kilty, 2004). This information also represents a type of "official" knowledge.

Racial and ethnic categories exist outside of these "official" sources. The popular media detail how public officials and the general public identify different groups. Throughout the history of this country the mass media has been used by those in power to raise concerns about the nature of particular racial and ethnic groups. Efforts to limit immigration, to remove certain public benefits, to challenge educational activities, to keep different groups separated from each other - all reflect attempts to maintain existing social hierarchies or to establish new ones. It would 


\section{Ethnic Studies Review Volume 27: 1}

be useful to examine how popular categorizations are correlated with so-called official designations.

A final source of information on racial and ethnic group categorization is to be found in the writings and activities of advocacy groups. Social movements have influenced ideas about and images of groups throughout $U$. S. history. Such movements have often led to the development of civil rights organizations, such as the National Association for the Advancement of Colored People and the National Council of La Raza. How such organizations have accepted or challenged prevailing ideas is an important matter to consider. As noted earlier, advocacy groups had a significant impact on the racial and ethnic categories used in the $2000 \mathrm{U}$. S. census.

\section{Classifying Latinos: Latinos and the U. S. Census}

The first national census was conducted in 1790, a little more than a year following the ratification of the Constitution. Article I, Section 2 of the Constitution calls for an enumeration of the nation's population every ten years at a minimum. The requirement emanates from a compromise that emerged at the Constitutional Convention that gave all states, large and small, equal representation in the Senate, but tied representation in the House to population size. In addition to the need for enumeration for House representation purposes, since the 1960 Supreme Court "one person, one vote" ruling the Census is needed to insure the rulings requirement that congressional districts within a State and State and local legislative districts to be of nearly equal population. Furthermore, the allocation of Federal and State funds is also, in part, related to census figures. Racial data collected in the census provide the basis for implementing equal opportunity, affirmative action, and some employment legislation. While the official purpose of the Census is related to the representative nature of our government as established in the Constitution and Supreme Court rulings, its contemporary uses greatly exceed this narrow application. The census has tremendous utility for market studies, academic research, affirmative action programs, and public and private planning activities (U.S. 
Dept. of Commerce, 1992). In short, being counted and how one is counted, or classified, is of tremendous import.

As noted earlier, one of the ways in which the census classifies individuals is by race. A "race" or "color" question has been asked in each census since 1790. Other than "sex," it is the only other population item that has been consistently asked of all respondents since the first census. In the 210 years that the census has been conducted, however, racial categorizations have changed from decade to decade. The first census was quite crude, only producing separate counts for white males sixteen years of age and older, white males under the age of sixteen, free white women, all other free persons, including any American Indians who paid taxes, and slaves (U. S. Department of Commerce, 1992). In 1850 the category of Mulatto was introduced to distinguish the "color" of slaves and in 1870, the first census to follow the Emancipation Proclamation, enumerators were instructed that the "Color" column was always to be completed, since one could no longer assume "White" for "Free Inhabitants" and "Black" for "Slave Inhabitants" since the free and slave designations were no longer relevant. Furthermore, enumerators were instructed to be careful to designate any individual with any "perceptible trace of African blood" as Mulatto. Also in this census year, "Chinese" was added to the racial categorization scheme. Since this time the census has always included some type of "White," "Black," "Asian", and "Indian" category.

While Whites, Blacks, and Native Americans have been counted in one way or another, albeit imperfect and incomplete, in each census since its inception, and some Asians since 1870, Latinos have not been counted in a systematic and uninterrupted way. In 1930 "Mexicans" were counted. Enumerators were offered the following choices in response to the item "Color or race:" White, Negro, Mexican, Indian, Chinese, Japanese, Filipino, Hindu, or Korean. Instructions to enumerators read "In order to obtain separate figures for Mexicans, it was decided that all persons born in Mexico or having parents born in Mexico who were not definitely White, Negro, Indian, Chinese, or Japanese, would be returned as Mexicans" (U. S. Department of Commerce 1979, 52). In the 1940 census "Mexican" was 


\section{Ethnic Studies Review Volume 27: 1}

dropped from the list of responses, and enumerators were instructed to classify Mexicans as White unless they were "definitely Indian or some race other than White" (U. S. Department of Commerce 1979, 61).

In 1960 these instructions were expanded: "Puerto Ricans, Mexicans, or other persons of Latin descent should be classified as 'White' unless they were definitely Negro, Indian, or some other race" (U. S. Department of Commerce 1979, 70).

Interestingly, while the 1950 and 1960 census did not have a racial or ethnic population item or category to identify Hispanics, and enumerators were generally told to list them as "White," ex post facto attempts were made to classify them as a distinct group. The identification of Hispanic individuals was done after census questionnaires had been completed based on Spanish surnames of householders. Identification of Spanish surname was first used by the census in 1950 and later in 1960 and 1970. This was done only in Arizona, California, Colorado, New Mexico, and Texas and involved a manual coding operation based on an U. S. Immigration and Naturalization compilation of Spanish surnames. For the 1970 census the list was expanded by adding surnames that had twenty-five or more listings in the Havana, San Juan, and Mexico City, telephone directories, as well as surnames reported as Spanish-ethnic backgrounds in the 1968 October-December Urban Employment Survey and surnames taken by a study titled "The Romance of Spanish Surnames." Coders were directed to code as Spanish any surname ending in $a, e s, n$, no, os, s or $z$ in which the preceding part of the name appeared on the official list. Surnames with a prefix of De, Del, De La, De Las, or De Los were also coded as Spanish. "Martin" was coded as a Spanish surname if either parent of the individual bearing that name was born in a Spanish speaking country or the person indicated that Spanish was their native tongue or that $\mathrm{s} / \mathrm{he}$ was of Spanish origin (U. S. Department of Commerce, 1980). The 1970 census also generated Spanish Surname data using the ex post facto coding method for the five southwest states to provide historically comparable data with that of the 1950 and 1960 census.

The 1970 census, however, asked a five percent sample of 


\section{Kilty and Haymes-Classifying}

the total U. S. population if their "origin or descent" was "Mexican, Puerto Rican, Cuban, Central or South American, other Spanish, or none of these." This item was followed by the color or race question, but not immediately (nine items in between). In cases where individuals had responded affirmatively to the Spanish origin item and had written in "Chicano," "La Raza," "Mexican-American," or "Brown" on the race item, the census bureau recorded the latter as White (U. S. Department of Commerce 1979, 75). This marked the beginning of the continuous inclusion of a Hispanic/Latino indicator in the $U$. S. census.

The 1980 census included a similar Spanish origin item, but collapsed the "Central or South American" and "Other Spanish" categories into one: "other Spanish/Hispanic." This change introduced the term "Hispanic" into the official census form. Furthermore, the 1980 census extended the Hispanic identifier item to all households, rather than a sample of households. Also, the response "No, not (Spanish/Hispanic)" was moved up to the first response option to clarify that this question pertained to all respondents. This question was also placed closer to the race item in the questionnaire, now following it after two other items. New instructions for enumerators did not allow them to enter race by "observation" rather they were directed to report the race with which the person most closely identified. In the case of racial mixture, the mother's race, or the first racial group given was to be reported. Also in contrast with the 1970 census, responses such as Mexican-American, Chicano, or Brown, were to be coded as "Other" for the race item if one of the listed categories was not selected. Furthermore, if a person indicated more than one ancestry in the Spanish-origin question and only the second ancestry mentioned was Spanish (e.g. Irish-Mexican), the person was to be marked as "no, not Spanish /Hispanic" (U. S. Department of Commerce, 1979, 81).

In 1990 the Spanish origin question remained essentially the same as the 1980 version with one exception. Individuals indicating "Yes, other Spanish/ Hispanic" were asked to write in which group (e.g. Argentinean, Colombian). However, the writein responses were only reviewed and coded for the sample or long-form questionnaires (20\%). 


\section{Ethnic Studies Review Volume 27: 1}

Effective with the Census 2000 the Revised Standards for the Classification of Federal Data on Race and Ethnicity changed the aforementioned 1977 Statistical Directive No. 15 of the Office of Management and Budget (OMB), Office of Information and Regulatory Affairs in several significant ways. First, the revised standards detailed five categories for data on race: American Indian or Alaskan Native, Asian, Black or African American, Native Hawaiian or Other Pacific Islander, and White. The Bureau of the Census was also directed to allow for the reporting of more than one race. Furthermore, two categories for data on ethnicity were specified: "Hispanic or Latino," and "Not Hispanic or Latino." The OMB defined Hispanic or Latino as "a person of Cuban, Mexican, Puerto Rican, South or Central American, or other Spanish culture or origin, regardless of race." For the purposes of the 2000 Census and a few other federal data collection activities, the OMB approved the inclusion of a sixth racial category, "some other race," for respondents unable to identify with any of the five preceding categories (U. S. Department of Commerce 1997, 15).

The question on Hispanic origin for the 2000 census was similar to the 1990 census question except for its placement on the questionnaire. For the 2000 census it immediately preceded the question on race, reversing the order from the 1990 census. This placed the race and Hispanic origin items next to each other, a change from earlier censuses that separated the two with other questions such as age and marital status. The most significant change on the race question on the 2000 census was the option of selecting one or more race categories offered to respondents (U. S. Department of Commerce, 2001).

Within this categorization scheme, $48 \%$ of Latinos responding to the 2000 census question on race reported that they were only "White," $42 \%$ reported only "Some other race," $2 \%$ indicated Black or African American alone, 1.2\% indicated American Indian and less than $1 \%$ indicated Asian or Native Hawaiian alone. Of the 15.4 million people who reported "Some other race" alone, 97\% were Latino. Furthermore, some $6.3 \%$ of Hispanics reported two or more races, in contrast to less than $2 \%$ of non-Hispanics (U. S. Department of Commerce, 2001). 


\section{Racial Observations and Self-Identification: Changes in the Census}

The numerous definitional changes regarding racial and ethnic categorization previously discussed have all occurred in changing social and political contexts. For example, the Civil War replaced the "Free Inhabitant" and "Slave Inhabitant" categories with "White, Black, Mulatto, and Chinese" categories. The Civil Rights and Black and Brown power movements led to a substitution of "Negro" with "Black" and an introduction of the term "Chicano" on the Census forms. Technical innovations also transformed the way the census has been conducted. Up until the 1960s enumerators that canvassed door-to-door conducted the census. The 1960 census began a shift towards the use of the mail system and computerized coding and analysis of forms. The 1960 census was the first to be tabulated entirely by computer and introduced a self-enumeration method on a limited basis and the first in which the mail system was used extensively. By the 1970 census approximately $60 \%$, those who resided in large metropolitan areas, were sent the census questionnaires by mail and were asked to return completed forms by mail. Enumerators were only used to contact households that had failed to return a completed form (U.S. Department of Commerce 1980, 30-33). By $1980,90 \%$ of household received their census form by mail. Again enumerators were only visited homes that did not return completed surveys.

This period of transition from enumerator-completed forms to self-enumeration methods had significant implications for racial categorizations as it also represented a shift from enumerator "observed" race to racial self-identification. In 1980 enumerators were no longer allowed to enter race by "observation." This shift is more than a practical one, driven by changes in methodology. It also represented a paradigmatic shift in some ways in that it moved from "objective" observational categorization to subjective "self identification of race, from "scientific or biological " to "social or political" notions of race. This alteration is reflected in the various official census related publications released over the 210 years the census has been conducted. For example the instructions to enumerators for the 1870 
Census directed them to take special care when reporting race, particularly with respect to the class of "mulatto," because "important scientific results depend upon the correct determination of this class." The "mulatto" category was to be used for any individual having "any perceptible [i.e. observable] trace of African blood" (U. S. Department of Commerce 1979, 18). Years later, in the 1990 Census of Population and Housing Guide (U.S. Department of Commerce 1992, 11), the Bureau of the Census notes that "the concept of race used by the Census Bureau is not intended to provide any clear-cut, scientific definition of biological stock, rather it represents the self-identification of the respondents" (U.S. Department of Commerce 1992, 11). More recently in the Office of Management and Budget revisions of Statistical Directive No. 15, Race and Ethnic Standards for Federal Statistics and Administrative Reporting states that the categories in the classification scheme are "socio-political constructs and should not be interpreted as being scientific or anthropological in nature" (U.S. Department of Commerce 1997, 15).

This statement is a clear change in intent from earlier periods where the census identified its categories as concrete and objective to a situation where the census bureau is acknowledging that race and ethnicity are not "scientific" ideas. Omi and Winant's theory of racial formation presents race as a social construction. By this they mean that race is neither a fixed, concrete, objective reality, nor is it a pure illusion, fiction, or ideological construct. They argue that it has elements of both in that race is "a concept which signifies and symbolizes social conflicts and interests by referring to different types of human bodies" (Omi \& Winant, 1994, 55). From this vantage point, racial categories are created, lived, and transformed through a sociohistorical process of "racial projects" that ideologically link structure and cultural representation. As Nobles (2000) points out, understanding racial and ethnic concepts means treating them as "discourse," a point of view that the U. S. Census Bureau now seems to be adopting.

In the particular case of Latinos Winant (1994) asserts that the social category of "Hispanic" resulted from the racialization 
of the various Latin American ethnic groups in the U. S. context. Latin American groups with distinct identities, national origins, histories, cultures, and antagonisms were amalgamated into one group through a process of panethnicity. This amalgamation emanates from the dynamic relationship between the group being racialized and the state. The intellectual and political elite of the group strategically uses the numbers and resources that a panethnic bloc can wield to make political demands, while the state benefits from recognizing and responding to a large bloc, rather than an unmanageable multitude of ethnic interest groups. According to Munoz (1987, 36), the term Hispanic emerged in the corridors of the federal government in the 1970s after the decline of the Chicano Power Movement. For federal bureaucrats, it provided a convenient category to group all immigrants from Latin America and their descendants in the context of social welfare programs. For the five elected congressmen of Latin American origins (one Puerto Rican and four MexicanAmericans), it provided a vehicle to promote coalition politics amongst their respective Spanish-speaking constituents as well as aiding them in forming a caucus which elevated their power in the U.S. Congress.

\section{Changes in the Census and "Other Race" Constructs}

The census move towards self-identification of race has led to an observable difference or ambivalence in how Latinos view themselves racially and how others outside of the Latino community view them. More specifically, nearly half (or 48\%), of Latinos indicated that they were White alone while an equal number indicated that they were "some other race" alone (42\%) or mixed-race $(6 \%)$. Of the Latinos reporting more than one race $81 \%$ reported only two races with one being "some other race." Two percent indicated that they were Black, 1.2\% American Indian alone, $0.3 \%$ Asian alone, $0.1 \%$ Native Hawaiian and other Pacific Islander alone. "Other race" or "mixed race" constructs have commonly been associated with Latinos. La Raza, the cosmic race, mestizo, Creole, and the rainbow race are all terms that have been applied internally by Latinos to describe the racial-hybridity that has characterized the people of Latin 


\section{Ethnic Studies Review Volume 27: 1}

America. As an internal-racial project, the rainbow race has meant something different to Latinos than is has to white Americans. As an external racial project it has meant a nonwhite racialization process for Latinos in the U. S. (Grosfoguel and Georas, 1996)

In the context of the U.S., the in-betweenness of the rainbow race has been engaged in two contradictory ways as advanced by different political tendencies within the Latino leadership. The ambiguity regarding the question of race inherent in the rainbow race construct, when inserted in a binary understanding of race which characterizes the U. S., has created a situation in which Latinos can make claims at either end of the rainbow spectrum: White or Black. In other words two distinct racial projects have been advanced by Latino political elites, one racial project attempts to align Latinos more closely with whites, while the other attempts to do so with nonwhite groups.

In his analysis of Chicano politics, Munoz (1987) argues that middle class Mexican-American political organizations, such as the League of United Latin American Citizens (LULAC), the Mexican American Political Association (MAPA) and the Political Alliance of Spanish Speaking Organizations (PASSO) have all pursued a politics of assimilation and accommodation, choosing to identify with Whites in exchange for acceptance. More specifically, Munoz $(1987,39)$ asserts that while some groups have not rejected their Mexican culture, they have fostered a white identity outside of the Chicano community as a political strategy. In other words, pan-ethnic, rainbow race, cultural identity and solidarity is advanced internally while a white assimilationist strategy is advanced outwardly.

In contrast Munoz argues that the Chicano Power Movement of the 1960s and 1970s attempted to "shape a politics of Chicano unification on the basis of nonwhite identity and working class interests." This movement had its beginnings in the farm workers struggle lead by Cezar Chavez and the Chicano student movement, which produced several organizations across the nation, such as MECHA, El Movimiento Estudiantil Chicano de Aztlan. Later non-student youth groups such as the BrownBerets and other community organizations formed to support the 
same political trend. These reformulations of Latino identity, in this case specifically Mexican American, directly challenged middle class Mexican-American political organizations. While aforementioned organizations such as LULAC and MAPPA sought incorporation into the dominant institutions, the central objectives of the Chicano Power Movement were a "quest for a non-white identity and the struggle for political and economic power through the development of independent Chicano institutions and community control over existing institutions" (Munoz, 1987, 42).

\section{Official Classification and Latino Identity}

More recent maneuvers around the fixing of census categories continue the exploitation of the racial ambivalence of Latinos for varied political projects. Goldberg argues that major purpose of the census "has always been to manage effective resource distribution and voting access" and "these economic and political mandates in the United States have always been deeply racialized" $(1995,245)$. He also asserts that due to the racial hybridity of Latinos, their racial self-identification in the census is vulnerable to the changing interest of those who have the power to define the categories. As the Latino population in the U.S. continues to rapidly grow, Goldberg argues, the political stakes are heightened in regard to which end of the rainbow spectrum Latinos will identify with in the census:

One of the subtly silent ways remaining available to dilute blacks' voting rights, perhaps one of the only permissible alternatives now, is to set them against "other" statistically dominant "minorities," minorities whose racial configurations are precisely ambiguous. Blacks are marked hegemonically as politically and socially liberal (and in the 1980s liberal came to be cast as literally un-American); Hispanics (and perhaps also Asian Americans) are often cast as socially (and perhaps economically) conservative...78 percent of black voters support the Democratic Party compared to 54 percent of the "Hispanic" voters, and only 34 percent of 


\section{Ethnic Studies Review Volume 27: 1}

Whites. In the managed tensions between liberals and conservatives that characterize $U$. S. politics, the drive to bring Hispanics under the "right" wing is on...A social statistics that purports to report the truth may be party to the next big lie, the new racialized dynamics. This new dynamic of racialized fabrication may be fueled paradoxically by the very instrument designed to democratize the social body count, namely, racial selfidentification (Goldberg 1995, 246).

One of the most remarkable findings from the Census 2000 was the tremendous growth of the Latino population. National Census figures indicate that the Latino population grew by $58 \%$ since the previous census, reaching 35.3 million by the time of the 2000 census. In just two years later, the Latino population had grown by an additional $9.8 \%$, reaching 38.8 million or $13.4 \%$ of the total U.S. population (Ramirez and de la Cruz, 2002). This number marked the Latinos as is the nation's largest minority community, a demographic shift that many are predicting will have broad implications for the political landscape of the U.S. True to Goldberg's predictions, political jockeying to gain the Latino vote has heightened. At issue here is how the "Latino" vote is seen by various groups, including the dominant "white" or "Anglo" group in this country or by other minorities who may attempt to develop coalitions.

What it means to be Hispanic or Latino is a complex issue. The numbers seem to have skyrocketed in the recent past. In 1930, 1.3 million Mexicans were reported in the $U$. S. census, while 2.3 million "persons of Spanish surname" were reported in the 1950 census. Then in 1970, 9.1 million were counted, followed by 14.6 million in 1980 and 22.4 million in 1990 (U. S. Department of Commerce, 1993). The 2000 census reported 35.3 million Hispanics (U. S. Department of Commerce, 2001).

One of the critical questions here, though, is the extent to which Hispanics have been counted accurately in the past. By not being specifically identified, it would be a simple matter for authorities (and most members of the dominant racial/ethnic group) to ignore them - and therefore not to count them at all. 
Throughout the first century of their presence in the $U$. S. (i.e., from 1850 to 1950), there seems to have been little formal identification by the Census Bureau. Yet as we showed earlier, Anglos clearly saw and related to Hispanics in the U. S. Southwest (formerly the northern half of Mexico) in racial terms i.e., in a discriminatory manner (e.g., Gonzalez, 2000; Gordon, 1999). Not identifying makes it easy to ignore a group, potentially limiting group awareness and the emergence of group solidarity, while ensuring institutionalized biased treatment.

Now the existence of Hispanics is being established in the form of racial and ethnic categories, particularly since Statistical Directive No. 15 and its modification for the 2000 census. There is still the issue of whose interests are being served by this codification process (i.e., the racial project). Population growth has shifted to new areas of the country, affecting apportionment and redistricting as well as the allocation of federal funds and the potential enforcement of civil rights legislation. Further, identifying groups through census categories can be a tool for separating and dividing minorities of color. Racialization, then, can serve the interests of a minority (particularly an emerging group) by providing a mechanism around which social action and group solidarity may develop. At the same time, it can be used by the dominant group as a wedge to split potential allies, thus helping to maintain the superiority of the dominant group.

\section{References}

Babbie, E. R. (2001). The practice of social research. (9th ed.). Belmont, CA: Wadsworth Thomas Learning.

Bowker, G. C., \& Star, S. L. (1999). Sorting things out: Classification and its consequences. Cambridge, MA: MIT Press.

Deloria, V., Jr., \& Lytle, C. (1984). The nations within: The past and future of American Indian sovereignty. New York: Pantheon.

Farley, J. E. (2000). Majority-minority relations. (4th ed.). Englewood Cliffs, NJ: Prentice-Hall. 
Feagin, J. jR., Vera, H., \& Batur, P. (2001). White racism. (2nd ed.). New York: Routledge.

Garcia, J. R. (1980). Operation wetback: The mass deportation of Mexican undocumented workers in 1954. Westport, CT: Greenwood.

Goldberg, D. T. (1995). Made in the USA. In N. Zack (Ed.), American mixed race: The culture of microdiversity (pp. 237-256). Lanham, MA: Rowman \& Littlefield.

Gonzalez, J. (2000). Harvest of empire: A history of Latinos in America. New York: Viking.

Gordon, L. (1999). The great Arizona orphan abduction. Cambridge, MA: Harvard University Press.

Grosfoguel, R \& Georas, C. (1996). The racialization of latino Caribbean migrants in the New York metropolitan area. Centro, 8(1/2), 191-201.

Kilty, K. M., \& Joseph, A. (1999). Institutional racism and sen tencing disparities for cocaine possession. Journal of Poverty, 3 (4), 1-17.

Kilty, K. M., \& Vidal de Haymes, M. (2000). Racism, nativism, and exclusion: Public policy, immigration, and the Latino experience in the U. S. Journal of Poverty, 4 (1/2), 1-25.

Meenaghan, T. M., Kilty, K. M., \& McNutt, J. G. (2004) Social Policy Analysis and Practice. Chicago: Lyceum.

Morales, P. (2001). Latinos and the "other race" option: Transforming U. S. concepts of race. NACLA Report on the Americas, XXXIV (6), 40-44. 


\section{Kilty and Haymes-Classifying}

Munoz Jr., C. (1987). Chicano politics: The current conjecture. In M. Davis, M. Marable, F. Pfeil, \& M. Sprinker (Eds.), The year left 2: An American socialist yearbook (pp. 35-52). Stony Brook, NY. New Left Books.

Nobles, M. (2000). Shades of citizenship: Race and the census in modern politics. Stanford, CA: Stanford University Press.

Omi, M., \& Winant, H. (1994). Racial formation in the United States. New York: Routledge.

Ramirez, R.R. and de la Cruz (2002). The Hispanic Population in the United States: March 2002, Current Population Reports, P20-545.

Washington, DC: U. S. Census Bureau.

Schaefer, R. T. (2000). Racial and ethnic groups. (8th ed.). Englewood Cliffs, NJ: Prentice-Hall.

Takagi, R. (1989). Strangers from a different shore: A history of Asian Americans. New York: Penguin.

U. S. Department of Commerce. (2001). The Hispanic Population. (Census 2000 Brief, C2KBR/01-2). Washington, DC: U. S. Census Bureau, Economics and Statistics Administration, U. S. Department of Commerce.

U. S. Department of Commerce. (2001). The Hispanic Population. (Census 2000 Brief, C2KBR/01-3). Washington, DC: U. S. Census Bureau, Economics and Statistics Administration, U. S. Department of Commerce.

U. S. Department of Commerce. (2001). Overview of Race and Hispanic Origin. (Census 2000 Brief C2KBR/01-1).

Washington, DC: U. S. Census Bureau, Economics and Statistics Administration, U. S. Department of Commerce. 
Ethnic Studies Review Volume 27: 1

U. S. Department of Commerce. (2000). Revisions to the Standards for the Classigication of Federal Data on Race and Ethnicity. Washington, DC: U. S. Census Bureau, Population Division, U.S. Department of Commerce.

U. S. Department of Commerce. (1993). We the American Hispanics. Washington, DC: U. S. Census Bureau, Economics and Statistics Administration, U. S. Department of Commerce.

U. S. Department of Commerce. (1992). 1990 Census of Population and Housing, Guide Part A. Text. Washington, DC: U. S. Census Bureau, Economics and Statistics Administration, U. S. Department of Commerce.

U. S. Department of Commerce. (1980). Census '80: Continuing the Fact Finder Tradition. Washington, DC: U. S. Census Bureau, Economics and Statistics Administration, U. S. Department of Commerce.

U. S. Department of Commerce. (1979). Twenty Censuses: Population and Housing Questions 1790-1980. Washington, DC: U. S. Census Bureau, Economics and Statistics Administration, U. S. Department of Commerce.

Vidal de Haymes, Maria, Haymes, Stephen, and Keith Kilty (2002). A new kind of rainbow politics: Latinos and the question of race. Journal of Human Behavior and the Social Environment 5 (3/4), 175-188.

Wilson, W. J. (1978). The declining significance of race. Chicago: University of Chicago Press.

Winant, H. (1994). Racial conditions: Politics, theory, comparisons. Minneapolis, MN: University of Minnesota Press. 